\title{
R\&D, Advertising and Firms' Financial Performance in South Korea: Does Firm Size Matter?
}

\author{
Jian $\mathrm{Xu}^{1}$ (D), Feng Liu ${ }^{2}$ (D) and You-hua Chen ${ }^{3, *(\mathbb{D})}$ \\ 1 School of Management, Qingdao Agricultural University, Qingdao 266109, China \\ 2 Korea University Business School, Korea University, Seoul 02841, Korea \\ 3 College of Economics \& Management, South China Agricultural University, Guangzhou 510642, China \\ * Correspondence: yhchen214@scan.edu.cn
}

Received: 17 June 2019; Accepted: 7 July 2019; Published: 10 July 2019

check for updates

\begin{abstract}
Advertising and research and development (R\&D) are two engines for firms to obtain competitiveness and improve profits. This study develops a system of equations to investigate the overall relationships among $R \& D$, advertising and financial performance across firm sizes. Data from Korean listed firms have been used during 2012-2016. First, our results show that R\&D and advertising are complementary in South Korea. Second, for large firms, advertising is positively and significantly associated with financial performance, and the R\&D expenditure has no significant influence. Finally, R\&D and advertising expenditures have a negative impact on the financial performance of small firms. An additional analysis is conducted to examine the duration of R\&D and advertising. Our results from Korean listed firms contain important implications for academia as well as practitioners.
\end{abstract}

Keywords: R\&D expenditure; advertising expenditure; financial performance; firm size

\section{Introduction}

In the competitive business environment, businesses need to consider the importance of investment in advertising and research and development (R\&D). R\&D and advertising as intangible assets are important determinants of firm value and profitability. An intangible asset investment can improve the enterprise market competitiveness, which in turn affects the market performance of its product [1]. Firms should decide on the amount of R\&D and advertising investments given their resource constraints, consistent with the resource-based view (RBV) [2,3]. In other words, large firms generally have more resources to allocate than small firms. Studies on the value-relevance of R\&D and advertising expenditures are one of the hottest issues in theory and practice [4-9].

$R \& D$ and advertising strategies are essential for the sustainable development of a firm. R\&D and advertising can increase market value [1] and reduce firm risk [10,11]. Peterson and Jeong [5] found that higher $R \& D$ and advertising expenditures lead to a better financial performance of large firms. However, some studies have shown that the effects of $R \& D$ and advertising do not appear to be widespread. For example, Bublitz and Ettredge [12] reported a negative relationship between advertising and the market value. Lantz and Sahut [13] found that R\&D is negatively related to the financial performance of technological firms. Steenkamp and Fang [14] proposed that the effect of advertising is small or even insignificant for U.S. firms. The reason for these conflicting observations still remains unclear.

In the context of Industry 4.0, competitive enterprises usually maintain high R\&D and advertising investments. Many firms in South Korea are increasing their R\&D investments and launching new advertising projects, and many Korean brands have established a global reputation [15]. For example, Samsung Electronics Co., Ltd., the world's second largest information technology company by revenue 
after Apple, spent 14.91 trillion won (US\$ 12.7 billion) and 5.4 trillion won (US\$ 4.6 billion) on R\&D and advertising in 2017, about 6.22 percent and 2.25 percent of its annual sales, respectively. Meanwhile, $R \& D$ and advertising expenditures are massive in developed countries, e.g., above 2 percent of the gross domestic product (GDP) in the US [16]. South Korean R\&D investment as a percentage of its GDP rose from $3.466 \%$ in 2010 to $4.227 \%$ in 2016, ranking second in the world. In contrast to many other countries, Korea's R\&D intensity is largely driven by firms [15]. However, in the Korean market, some firms are more likely to overinvest or underinvest in R\&D and advertising, which results in the variability of firms' financial performance [4]. Therefore, we need to make more theoretical and empirical research on $R \& D$ and advertising investments to guide the behaviors of Korean firms' investment.

In order to improve the reliability and comparability of accounting information, the Korean government adopted International Financial Reporting Standards (IFRS) and announced the Korean International Financial Reporting Standards (K-IFRS), requiring listed companies to generate their financial reports based on new accounting standards from 2011 [17]. After the introduction of K-IFRS, the question of whether R\&D and advertising expenditures can enhance Korean firms' financial performance is still a concern that attracts scholars and practitioners. Firm-level data are collected from 589 firms listed on the Korea Stock Exchange during 2012-2016. This study aims to examine how R\&D and advertising expenditures affect the financial performance of Korean listed firms, and the connection between advertising and R\&D. In addition, we have investigated whether the firm size (measured by the sales revenue) affects the impact of $R \& D$ and advertising expenditures on the financial performance. Pindato et al. [18] suggested that the firm size positively affects the relationship between the firm value and R\&D spending. Chauvin and Hirschey [1] argued that R\&D and advertising can generate more profits for large firms than for small ones. However, even if scale advantages exist, small firms are more likely to make continuous investments in $R \& D$ and advertising in order to maximize their firm's value. In addition, Scherer and Ross [19] confirmed that the loss of marginal control and excessive bureaucracy in large firms leads to the low efficiency of R\&D and advertising investments, which indicates that the firm size may influence the relationship between $R \& D$ and advertising expenditures, and the financial performance. Previous research has tended to ignore the scale factor because different types of firms have different policies regarding R\&D and advertising. In particular, a larger firm can use more resources for $\mathrm{R} \& \mathrm{D}$ and advertising activities, while a smaller firm is more likely to control $R \& D$ and advertising expenditures.

Based on the aforementioned studies, we aim to answer the following research questions: (1) do $R \& D$ and advertising improve the financial performance of Korean firms after the adoption of K-IFRS, and if so, how? (2) does the firm size affect the impact of R\&D and advertising on the financial performance of Korean firms?

The contributions of this study are as follows. First, this study systematically examines the relationship between R\&D and advertising expenditures, and the financial performance, and the connections between $R \& D$ and advertising. Little research has been done on the interaction effect of $R \& D$ and advertising. Second, this study examines the effectiveness of $R \& D$ and advertising across firm size classes. Previous research has tended to ignore the scale factor, and little attention has been paid to comparing the economic effects of R\&D and advertising between large firms and small firms in recent decades. This study is designed to fill this gap in an emerging economy. Third, this study extends the extant literature and provides new evidence by using data from South Korea, an emerging market with a great growth potential and a very high level of investment in R\&D. To our knowledge, this study is the first to analyze these relationships after the introduction of K-IFRS. The majority of previous studies have tended to rely exclusively on U.S. or UK data, and only earlier studies (e.g., [4,20,21]) have focused on this relationship based on the data from Korean listed firms. Fourth, this study provides empirical evidence for corporate managers on how to effectively utilize intangible assets to ensure the sustainability of the financial performance.

The rest of the article proceeds as follows: Section 2 discusses previous research. This is followed by Section 3 that develops a set of hypotheses. Next, Section 4 presents the research methodology and 
sample selection. The details of tests and results are included in Section 5. Finally, conclusions are presented in Section 6.

\section{Literature Review}

\subsection{RED and Advertising}

An emerging body of research explores the optimal R\&D and advertising investment strategies for enterprises. Zhang and Fu [22], for example, found that firms with fewer R\&D costs should pay attention to the influence of rival advertising in a dynamic duopoly. In terms of the correlation between R\&D and advertising, Connolly and Hirschey [23] reported a negative coefficient on advertising in the $R \& D$ equation, and suggested that $R \& D$ and advertising represent a competing use of funds. However, advertising and R\&D spending are likely to be complementary activities with respect to product differentiation. An early study conducted by Farber [24] suggested that the advertising intensity significantly increases the R\&D intensity. By using a four-equation model and a sample of Japanese leader firms, Nakao [25] pointed out that an increase in the advertising investment leads to an increase in the R\&D input. Ren [26] found that they are complements in China's high-tech industry. Additionally, Graevenitz and Sandner [27] showed that advertising is a complement to $R \& D$ for innovation intensive firms, and that $R \& D$ is not a complement to advertising for advertising intensive firms. The findings of Chen et al. [28] also suggested that advertising is complementary with $R \& D$ in manufacturing firms, while it is competitive with R\&D in non-manufacturing firms.

\subsection{RED and Advertising Expenditures and Financial Performance}

A number of theoretical models demonstrate that the financial performance can be seen as being a function of $R \& D$ and advertising [23,29]. The existing empirical evidence on the relationship between $R \& D$, advertising and the financial performance is mixed. An early study by Nakao [30] reported that $R \& D$ is as important as advertising in determining a firm's profitability and industry concentration. Hirschey and Weygandt [31] subsequently tested the linkages among them. They pointed out that both the R\&D intensity and advertising intensity positively affect Tobin's q. Taking U.S. manufacturing firms as a sample, Hall [32] found that R\&D and advertising are positively related to the firm value. Based on the U.S. manufacturing sector, Andras and Srinivasan [33] reported evidence that R\&D and the advertising investment can improve a firm's profitability. However, Han and Manry [4] and Li [34] argued that the R\&D expenditure has a positive impact on the stock price and that the advertising expenditure has a negative impact. Xing and Yang's [35] findings show that R\&D and advertising expenditures significantly affect the main operating profit of Chinese pharmaceutical companies, and that the R\&D expenditure has a greater influence than the advertising expenditure. In addition, Steenkamp and Fang [14] confirmed that the impact of R\&D and advertising on the enterprise economic performance varies with the economic cycle.

In terms of the interaction of R\&D and advertising, Connolly and Hirschey [23] found a negative R\&D-market concentration interaction effect. Ma et al. [36], using Chinese data, argued that this interaction is positively related to the enterprise economic performance only in pharmaceutical manufacturing and telecommunication, computer and other electronic equipment manufacturing industries.

Because of the inconsistent findings in prior work, this study proposes a systematic test of this relationship. Furthermore, this study attempts to conduct deep research on the interaction of R\&D and advertising.

\subsection{Firm Size Effect}

Chan et al. [37] and Doukas and Switzer [38] found a positive link between R\&D spending and the firm's market value, especially in large high-tech firms. Chauvin and Hirschey [1] found that size advantages (economies of scale) make advertising and R\&D relatively more profitable for larger firms. 
The findings of Cho et al. [39] showed that top ten firms in South Korea share 75 percent of the total R\&D expenditure. A research performed by Depken and Snow [40] showed that the advertising inputs of firms in the fringe of the industry lead to more advertising inputs of large firms. Based on the data from the questionnaire of 1621 new ventures, Mai and $\mathrm{Li}$ [41] concluded that $\mathrm{R} \& \mathrm{D}$ and advertising expenditures have a positive impact on the brand equity of new ventures and that advertising loses this effect after obtaining their financing.

\section{Hypotheses Development}

The interplay between $R \& D$ and advertising is mixed in previous studies. If advertising can bring higher returns than $R \& D$ activities, firms that face credit constraints or have to compel with short-run objectives are more willing to favor advertising, which results in a reduction of the R\&D effort [16]. However, advertising and R\&D may be complements. Advertising is generally used to improve quality, and the reputation of a famous firm might be damaged if this firm offers an odd or outdated product [42]. Advertising may be more efficient for R\&D-intensive firms or firms providing less costly goods or services. Advertising may also generate short-term rents that help to finance long-term investments, including through R\&D. Based on the above analysis, a positive relationship between R\&D and advertising expenditures is expected. We come to the following hypothesis:

Hypothesis 1 (H1). There is a positive relationship between RED and advertising, that is, RED and advertising expenditures are complementary.

$R \& D$ and advertising are two important drivers for firms to escape competition through a quality advantage or a better attraction power toward consumers [16]. The ultimate goal of R\&D investment is to improve the economic performance of the enterprise [43]. On the one hand, firms can obtain new products and processes through R\&D activities, which can yield competitive advantages over rivals [44]. On the other hand, $R \& D$ investment also determines product differentiation and quality, which is beneficial to the increase of the enterprise value [45]. Firms that succeed in innovation tend to develop prosperously, resulting in the increase in their market shares [46].

In general, R\&D has an economic life of more than one year, and such expenditures represent investments in valuable intangible assets [47]. Tax laws that permit an expensing of capital items result in substantial tax subsidies. Since tax subsidies have a real economic value, a positive effect of $R \& D$ on the financial performance will result. Therefore, we come to the following hypothesis:

Hypothesis 2 (H2). RED expenditure has a positive impact on the financial performance.

Advertising is a common phenomenon in an imperfectly competitive market. In a competitive market, the entire product of a firm can be sold at the market price without product advertising [48]. In addition, advertising is considered as an important corporate strategy that affects the total cost, product demand and firm profitability in a non-competitive market [36]. To achieve the goal of profit maximization, the managers in each firm have to decide on the level of intensity of a number of strategies. Depending on the managers' ability, the advertising intensity is a decisive factor affecting a firm's success or firm profitability.

Firms can use advertising to acquire a reputation or to publicize a better quality, intensity in innovation or even fashionableness of products or services. Advertising is also utilized to deter and accommodate entry and induce exit [49]. Advertising appears to have clearly positive impacts on firms' profits. Therefore, we come to the following hypothesis:

Hypothesis 3 (H3). Advertising expenditure has a positive impact on the financial performance.

Economists hold different opinions on the role of advertising in a market economy. Some economists argue that advertising tends to foster market power. First, it can impede the entry of new 
firms. If advertising is easily affected by economies of scale, new firms may be required to have a larger scale to achieve the average cost when entering markets. Compared with established firms in a market, potential entrants may also advertise more to convince prospective buyers that their products are as good, if not better, than the products of established sellers [50]. Second, it can establish brand loyalty in the minds of consumers [51].

$R \& D$ and advertising are considered to be two methods to enhance a firm's competitiveness [5]. $R \& D$ investment can improve the product quality. If enterprises do not pay great attention to advertising and marketing strategies, high-tech products might not improve their market value. On the contrary, if enterprises ignore $R \& D$ in innovation, this will result in the depreciation in the value of the current products. Therefore, R\&D activities are the foundation of brand creation, and the brand is the realization of the market valuation of R\&D. As the important competitive strategies, the aim of $R \& D$ and advertising is to meet the needs of consumers and obtain economic profits. This leads to our fourth hypothesis:

Hypothesis 4 (H4). The interaction of RED and advertising expenditures is positively related to the financial performance.

While the effects of R\&D and advertising on the market value are generally apparent, such aggregate evidence has the potential to obscure meaningful differences across firm size. Consistent with the fact that a majority of firms are not willing to invest a huge amount of money in R\&D and advertising, the valuation effects of R\&D and advertising are most uniformly evident in larger firms. Large firms are more likely to be responsible for substantial $R \& D$ and advertising spending in order to obtain competitive advantages, which leads to a high performance [47]. Small and medium-sized enterprises (SMEs) generally have strong innovation motivations, and they might obtain some technical breakthroughs [52]. Based on the RBV, the resource allocation of small firms plays a critical role in corporate sustainable development [53]. Compared with large firms, small firms are not likely to spend substantial amounts of money on both R\&D and advertising activities. Therefore, how to effectively utilize and distribute the limited resources has become an important issue facing small firms. Thus, we come to the following set of hypotheses:

Hypothesis 5a (H5a). Firm size affects the relationship between advertising and RED, that is, the impact of advertising on RED in large firms is stronger than that in small firms.

Hypothesis $\mathbf{5 b} \mathbf{( H 5 b )}$. The impact of the RED expenditure on the financial performance in big firms is stronger than that in small firms.

Hypothesis 5c (H5c). The impact of the advertising expenditure on the financial performance in big firms is stronger than that in small firms.

Hypothesis $\mathbf{5 d}(\mathbf{H} 5 \mathbf{d})$. The interaction effect on the financial performance between RED and advertising expenditures in big firms is stronger than that in small firms.

\section{Methodology}

\subsection{Data Collection}

We use DataGuide database to collect accounting information during 2012-2016 for all Korean firms listed on the Korea Stock Exchange. The Korean government adopted IFRS and announced the K-IFRS, requiring listed companies to generate their financial reports based on new accounting standards from 2011. Taking the adjustment time as well as the complete accounting year into consideration, the year 2012 is selected as the starting point. The initial search returns for 749 listed 
companies. We eliminate firms listed after the year 2012, firms with missing information and firms without December fiscal year-ends. In addition, finance, securities and insurance industries are also excluded from the sample. The total number of our sample is 2945 for 589 listed firms during 2012-2016. Firm-level rather than industry-level data are analyzed to ensure an exact match between the R\&D, advertising and financial performance figures.

\subsection{Variables}

There are several alternative financial performance measurements, such as the return on assets (ROA) and Tobin's q. Tobin's q captures the investment value of a firm assessed by investors, which is widely used by most researchers $[8,26,31,54]$ to measure the firm value. Compared with Tobin's q, ROA can better illustrate the profitability of executives in utilizing assets by shareholders and creditors. Consistent with the literature $[36,43,55-57], \mathrm{ROA}$ is taken as the indicator to measure the financial performance of a firm.

As other studies have done $[4,8,33,36,46,52,58,59]$, we consider the following indicators to measure $R \& D$ and advertising investments: (1) the R\&D intensity (RD), measured by the ratio of R\&D expenses to sales; and (2) the advertising intensity (AD), measured through the ratio of advertising expenses to sales.

Based on previous studies [8,26,59-61], we use the log of the total assets (Asset), debt ratio (Lev), and sales growth rate (Growth) as control variables. In addition, a year dummy is introduced to control for changes in the economic environment. Table 1 provides a list of the variables and how they are measured.

Table 1. Variable definition.

\begin{tabular}{ccc}
\hline Variable & Definition & Measurement \\
\hline ROA & Firm performance & Net income divided by the average total assets \\
RD & R\&D intensity & Annual R\&D expenses divided by the annual sales \\
AD & Advertising intensity & Annual advertising expenses divided by the annual sales \\
Asset & Firm size & Logarithm of the total assets \\
Lev & Debt ratio & Total liabilities to total assets \\
Sales & Sales growth rate & Percentage of growth in the annual sales \\
Year & Year & Dummy variable that takes 1 for the test year, 0 otherwise \\
\hline
\end{tabular}

\subsection{Model Specification}

Of primary concern to this study is the role of $R \& D$ and advertising as determinants of the financial performance of the firm. We construct a three equation system to test the hypotheses stated in Section 3. Equation (1) is utilized to test $\mathrm{H} 1$ and H5a.

$$
\mathrm{RD}_{\mathrm{i}, \mathrm{t}}=\alpha_{0}+\alpha_{1} \mathrm{AD}_{\mathrm{i}, \mathrm{t}}+\alpha_{2} \text { Asset }_{\mathrm{i}, \mathrm{t}}+\alpha_{3} \text { Lev }_{\mathrm{i}, \mathrm{t}}+\alpha_{4} \text { Sales }_{\mathrm{i}, \mathrm{t}}+\text { Year }_{\mathrm{t}}+\varepsilon_{\mathrm{i}, \mathrm{t}}
$$

where $i=1, \ldots, n$ and $t=1, \ldots, t$ represent the firm and year, respectively; $\varepsilon$ denotes the disturbance.

If $\mathrm{H} 1$ is accepted, it is expected that $\alpha_{1}$ is positive and significant. In order to make the study robust, we also use $\mathrm{AD}$ as the dependent variable and $\mathrm{RD}$ as the independent variable.

Equation (2) is utilized to test $\mathrm{H} 2, \mathrm{H} 3, \mathrm{H} 5 \mathrm{~b}$, and $\mathrm{H} 5 \mathrm{c}$.

$$
\operatorname{ROA}_{i, t}=\beta_{0}+\beta_{1} \operatorname{RD}_{i, t}+\beta_{2} \mathrm{AD}_{\mathrm{i}, \mathrm{t}}+\beta_{3} \text { Asset }_{i, \mathrm{t}}+\beta_{4} \operatorname{Lev}_{\mathrm{i}, \mathrm{t}}+\beta_{5} \text { Sales }_{\mathrm{i}, \mathrm{t}}+\text { Year }_{\mathrm{t}}+\varepsilon_{\mathrm{i}, \mathrm{t}}
$$

The R\&D investment is thought to improve the financial performance $[46,52,62]$. Therefore, $R \& D$ is expected to influence the financial performance positively $\left(\beta_{1}>0\right)$.

Paton [29] showed a strong positive relationship between advertising and sales. We expect the advertising intensity to have a positive influence on the financial performance; that is, an increase in advertising would improve the financial performance $\left(\beta_{2}>0\right)$. 
In addition, we expect a positive relation between the total assets and financial performance $\left(\beta_{3}>0\right)$. With regard to the debt ratio, we can argue that the higher the debt ratio, the lower the profitability; accordingly, the expected sign of $\beta_{4}<0$. When firms' sales revenue increases greatly, the total profits increase, anticipating that $\beta_{5}>0$.

To test for a possible interaction effect between $\mathrm{RD}$ and $\mathrm{AD}$, Equation (3) is used to test $\mathrm{H} 4$ and H5d. We expected an R\&D-advertising interaction effect $\left(\gamma_{3}>0\right)$.

$$
\mathrm{ROA}_{\mathrm{i}, \mathrm{t}}=\gamma_{0}+\gamma_{1} \mathrm{RD}_{\mathrm{i}, \mathrm{t}}+\gamma_{2} \mathrm{AD}_{\mathrm{i}, \mathrm{t}}+\gamma_{3} \mathrm{RD}_{\mathrm{i}, \mathrm{t}} \times \mathrm{AD}_{\mathrm{i}, \mathrm{t}}+\gamma_{4} \text { Asset }_{\mathrm{i}, \mathrm{t}}+\gamma_{5} \text { Lev }_{\mathrm{i}, \mathrm{t}}+\gamma_{6} \text { Sales }_{\mathrm{i}, \mathrm{t}}+\text { Year }_{\mathrm{t}}+\varepsilon_{\mathrm{i}, \mathrm{t}}
$$

Guided by the literature $[63,64]$, we split the full sample into two subsamples-large firms and small firms-on the basis of the median of sales (340,357.5404 million won). The mean of sales in large firms (5,183,389.5100 million won) is 33 times as much as that in small firms (155,091.7875 million won). The $t$-test is used to determine if two sets of data are significantly different from each other. We find that there is a significant difference in sales between large firms and small firms $(t=12.372, p<0.01)$. Then, each equation is estimated on the subsamples of large firms and small firms separately to see if the relationships differ for large firms from small ones.

\section{Results}

\subsection{Descriptive Statistics}

Table 2 presents the descriptive statistics of the selected sample. Panel A of Table 2 presents the descriptive statistics from 2012 to 2016. The ROA variable shows a decreasing trend in 2013 to 2014, followed by an increase in 2015 and 2016 (See Figure 1). An investment in R\&D might pay off handsomely in the future, but immediate expensing of R\&D expenditures can lead to a loss in the current period. The AD variable suggests a slower growth in advertising (Figure 2). Also, the RD variable illustrates a sharp increase in the R\&D activities for the entire sample period (See Figure 2).

Panel B of Table 2 provides the descriptive statistics for large and small firms. The financial performance measure (ROA) indicates that large firms have a better performance than small firms. Additionally, large firms have a mean RD of 0.0072, while small firms have a mean RD of 0.0083 . In developed countries, the ratio of the R\&D expenditure to sales in large and medium-sized firms generally ranges from $4 \%$ to $10 \%$. This means that Korean firms have a low level of technological innovation capability. The mean advertising intensity of large and small firms is $0.92 \%$ and $0.84 \%$, respectively. These data alone suggest that large firms tend to be advertising-intensive while small firms are more likely to focus on R\&D activities.

Table 2. Descriptive statistics.

\begin{tabular}{|c|c|c|c|c|}
\hline \multicolumn{5}{|c|}{ Panel A: Descriptive statistics by year } \\
\hline Year & $\begin{array}{l}\text { Mean level of the } \\
\text { R\&D intensity }\end{array}$ & $\begin{array}{l}\text { Mean level of the } \\
\text { advertising intensity }\end{array}$ & \multicolumn{2}{|c|}{ Mean performance } \\
\hline 2012 & 0.0073 & 0.0088 & \multicolumn{2}{|r|}{0.0192} \\
\hline 2013 & 0.0073 & 0.0088 & \multicolumn{2}{|r|}{0.0153} \\
\hline 2014 & 0.0079 & 0.0087 & \multicolumn{2}{|r|}{0.0135} \\
\hline 2015 & 0.0078 & 0.0088 & \multicolumn{2}{|r|}{0.0168} \\
\hline 2016 & 0.0085 & 0.0090 & \multicolumn{2}{|r|}{0.0236} \\
\hline \multicolumn{5}{|c|}{ Panel B: Descriptive statistics by firm size } \\
\hline Variable & All & Large firms & Small firms & Difference $t$-statistic \\
\hline ROA & 0.0177 & 0.0300 & 0.0054 & $7.721^{* * *}$ \\
\hline $\mathrm{RD}$ & 0.0077 & 0.0072 & 0.0083 & $-1.673 * *$ \\
\hline $\mathrm{AD}$ & 0.0088 & 0.0092 & 0.0084 & 0.968 \\
\hline Asset & 11.7087 & 12.2155 & 11.2021 & $56.212^{* * *}$ \\
\hline Lev & 0.4691 & 0.5223 & 0.4160 & $14.721 *$ \\
\hline Sales & 0.1567 & 0.2540 & 0.0594 & 0.977 \\
\hline
\end{tabular}






Figure 1. Firms' financial performance for Korean firms from 2012 to 2016.

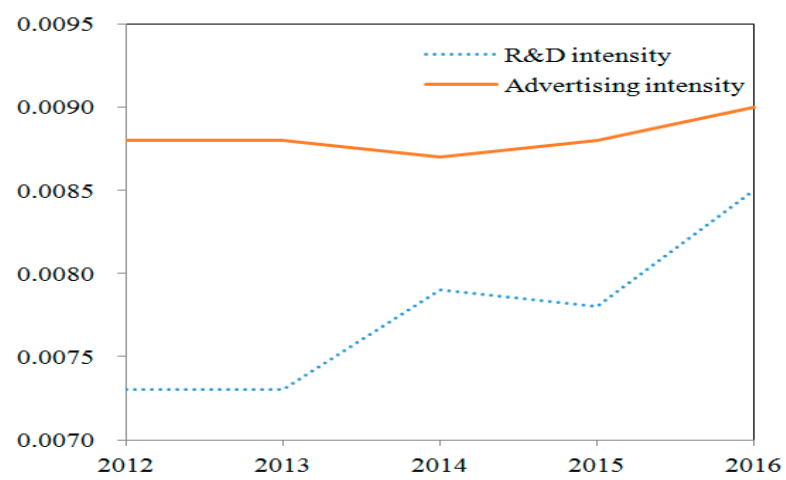

Figure 2. R\&D and advertising intensity for Korean firms from 2012 to 2016.

In fact, the DataGuide database reports that 168 out of 589 total firms have no R\&D activity, 31 out of 589 total firms have no advertising input and 35 out of 589 total firms have neither R\&D nor advertising input. It is relatively rare to find firms that report high levels of R\&D and advertising activity.

\subsection{Correlation Analysis}

In Table 3, Panel A shows the correlation for all firms. Panels B and C provide the correlation among the variables for large and small firms separately. For large firms, ROA is highly correlated with the R\&D expense (correlation of 9.7\%) and the advertising expense (correlation of $22.6 \%$ ) separately; and for small firms, ROA is not highly related with the advertising expense (correlation of $0.3 \%$ ). This suggests that the linear information dynamics is likely to be satisfied for large firms.

Table 3. Correlation matrix.

\begin{tabular}{|c|c|c|c|c|c|c|}
\hline \multicolumn{7}{|c|}{ Panel A: Pearson correlations for all firms } \\
\hline Variable & ROA & RD & $\mathrm{AD}$ & Asset & Lev & Sales \\
\hline ROA & 1 & & & & & \\
\hline RD & 0.003 & 1 & & & & \\
\hline $\mathrm{AD}$ & $0.087^{* * *}$ & $0.115^{* * *}$ & 1 & & & \\
\hline Asset & $0.171^{* * *}$ & 0.022 & $0.056^{* * *}$ & 1 & & \\
\hline Lev & $-0.305 * * *$ & $-0.117^{* * *}$ & $-0.149 * * *$ & $0.275^{* * *}$ & 1 & \\
\hline Sales & -0.018 & -0.006 & -0.003 & $0.034^{* *}$ & $0.039 * *$ & 1 \\
\hline \multicolumn{7}{|c|}{ Panel B: Pearson correlations for large firms } \\
\hline Variable & $\mathrm{ROA}$ & $\mathrm{RD}$ & $\mathrm{AD}$ & Asset & Lev & Sales \\
\hline ROA & 1 & & & & & \\
\hline RD & $0.097 * * *$ & 1 & & & & \\
\hline $\mathrm{AD}$ & $0.226^{* * *}$ & $0.063^{* * *}$ & 1 & & & \\
\hline Asset & $-0.054^{* *}$ & $0.120^{* * *}$ & 0.045 & 1 & & \\
\hline Lev & $-0.524 * * *$ & $-0.116^{* * *}$ & $-0.226^{* * *}$ & $0.174^{* * *}$ & 1 & \\
\hline Sales & $-0.052 * *$ & -0.009 & -0.007 & $0.036^{*}$ & $0.049^{* *}$ & 1 \\
\hline
\end{tabular}


Table 3. Cont.

\begin{tabular}{ccccccc}
\hline \multicolumn{7}{c}{ Panel C: Pearson correlations for small firms } \\
\hline Variable & ROA & RD & AD & Asset & Lev & Sales \\
ROA & 1 & & & & & \\
RD & $-0.046^{* *}$ & 1 & & & & \\
AD & 0.003 & $0.180^{* * *}$ & 1 & & & \\
Asset & $0.299^{* * *}$ & $-0.042^{*}$ & $0.104^{* * *}$ & 1 & & \\
Lev & $-0.286^{* * *}$ & $-0.110^{* * *}$ & $-0.087^{* * *}$ & $0.070^{* * *}$ & 1 & 1 \\
Sales & $0.056^{* *}$ & 0.027 & 0.025 & $-0.038^{*}$ & 0.022 & 1 \\
\hline \multicolumn{7}{c}{ Notes: $^{*} p<0.10,{ }^{* *} p<0.05,{ }^{* * *} p<0.01}$. \\
\end{tabular}

\subsection{Estimation Results}

We estimate the equations using ordinary least squares (used by, for example, [1,23,46,59,65-67]) to test our hypotheses. We compute the variance inflation factors (VIFs) and find them all to be under 5 , suggesting that multi-collinearity is not a major issue in our study. The regression results appear in Tables 4 and 5 .

Table 4. Regression results of Equation (1).

\begin{tabular}{|c|c|c|c|c|}
\hline Variable & Predicted Sign & All & Large Firms & Small Firms \\
\hline Constant & $?$ & $\begin{array}{c}-0.002 \\
(-0.448)\end{array}$ & $\begin{array}{c}-0.039 * * * \\
(-4.077)\end{array}$ & $\begin{array}{l}0.041^{* * *} \\
(2.765)\end{array}$ \\
\hline $\mathrm{AD}$ & + & $\begin{array}{l}0.078^{* * *} \\
(5.117)\end{array}$ & $\begin{array}{c}0.021 \\
(0.992)\end{array}$ & $\begin{array}{c}0.153 * * * \\
(6.887)\end{array}$ \\
\hline Asset & + & $\begin{array}{l}0.001 * * \\
(2.535)\end{array}$ & $\begin{array}{l}0.004^{* * *} \\
(5.431)\end{array}$ & $\begin{array}{l}-0.003 * * \\
(-2.071)\end{array}$ \\
\hline Lev & - & $\begin{array}{l}-0.010 * * * \\
(-6.025)\end{array}$ & $\begin{array}{c}-0.013^{* * *} \\
(-5.003)\end{array}$ & $\begin{array}{c}-0.008 * * * \\
(-3.547)\end{array}$ \\
\hline Sales & + & $\begin{array}{c}-7.84 \times 10^{-6} \\
(-6.025)\end{array}$ & $\begin{array}{c}-1.90 \times 10^{-5} \\
(-0.306)\end{array}$ & $\begin{array}{c}0.001 \\
(0.876)\end{array}$ \\
\hline Year & & Included & Included & Included \\
\hline adj. $R^{2}$ & & 0.024 & 0.032 & 0.042 \\
\hline $\mathrm{F}$ & & $19.203^{* * *}$ & $13.028^{* * *}$ & $17.238 * * *$ \\
\hline $\mathrm{N}$ & & 2945 & 1472 & 1473 \\
\hline
\end{tabular}

Table 5. Regression results of Equations (2) and (3).

\begin{tabular}{|c|c|c|c|c|c|c|c|}
\hline \multirow{2}{*}{ Variable } & \multirow{2}{*}{$\begin{array}{l}\text { Predicted } \\
\text { Sign }\end{array}$} & \multicolumn{3}{|c|}{ Equation (2) } & \multicolumn{3}{|c|}{ Equation (3) } \\
\hline & & All & Large Firms & Small Firms & All & Large Firms & Small Firms \\
\hline Constant & $?$ & $\begin{array}{l}-0.306^{* * *} \\
(-12.340)\end{array}$ & $\begin{array}{c}0.078^{* * *} \\
(2.910)\end{array}$ & $\begin{array}{l}-1.102 * * * \\
(-12.919)\end{array}$ & $\begin{array}{l}-0.307^{* * *} \\
(-12.351)\end{array}$ & $\begin{array}{c}0.078^{* * *} \\
(2.906)\end{array}$ & $\begin{array}{l}-1.101 * * * \\
(-12.907)\end{array}$ \\
\hline $\mathrm{RD}$ & + & $\begin{array}{c}-0.247^{* * *} \\
(-2.946)\end{array}$ & $\begin{array}{c}0.094 \\
(1.283)\end{array}$ & $\begin{array}{c}-0.377^{* *} \\
(-2.809)\end{array}$ & $\begin{array}{c}-0.283 * * * \\
(-2.652)\end{array}$ & $\begin{array}{c}0.098 \\
(0.974)\end{array}$ & $\begin{array}{c}-0.464^{* *} \\
(-2.561)\end{array}$ \\
\hline $\mathrm{AD}$ & + & $\begin{array}{c}0.082 \\
(1.182)\end{array}$ & $\begin{array}{c}0.285^{* * *} \\
(4.832)\end{array}$ & $\begin{array}{c}-0.265^{* *} \\
(-2.065)\end{array}$ & $\begin{array}{c}0.067 \\
(0.883)\end{array}$ & $\begin{array}{c}0.287^{* * *} \\
(4.600)\end{array}$ & $\begin{array}{l}-0.320 * * \\
(-2.223)\end{array}$ \\
\hline $\mathrm{RD} \times \mathrm{AD}$ & + & & & & $\begin{array}{c}2.092 \\
(0.536)\end{array}$ & $\begin{array}{c}-0.256 \\
(-0.057)\end{array}$ & $\begin{array}{c}4.896 \\
(0.399)\end{array}$ \\
\hline Asset & + & $\begin{array}{l}0.034^{* * *} \\
(15.709)\end{array}$ & $\begin{array}{c}0.002 \\
(1.095)\end{array}$ & $\begin{array}{l}0.106^{* * *} \\
(13.839)\end{array}$ & $\begin{array}{l}0.034^{* * *} \\
(15.713)\end{array}$ & $\begin{array}{c}0.002 \\
(1.087)\end{array}$ & $\begin{array}{l}0.106^{* * *} \\
(13.835)\end{array}$ \\
\hline Lev & - & $\begin{array}{l}-0.165 * * * \\
(-21.443)\end{array}$ & $\begin{array}{l}-0.156^{* * *} \\
(-21.473)\end{array}$ & $\begin{array}{l}-0.172 * * * \\
(-13.580)\end{array}$ & $\begin{array}{l}-0.165 * * * \\
(-21.447)\end{array}$ & $\begin{array}{l}-0.156^{* * *} \\
(-21.463)\end{array}$ & $\begin{array}{l}-0.172 * * * \\
(-13.594)\end{array}$ \\
\hline Sales & + & $\begin{array}{l}-0.0002 \\
(-0.731)\end{array}$ & $\begin{array}{l}-0.0002 \\
(-1.233)\end{array}$ & $\begin{array}{c}0.011^{* * *} \\
(3.333)\end{array}$ & $\begin{array}{l}-0.0002 \\
(-0.736)\end{array}$ & $\begin{array}{l}-0.0002 \\
(-1.232)\end{array}$ & $\begin{array}{c}0.011 * * * \\
(3.303)\end{array}$ \\
\hline Year & & Included & Included & Included & Included & Included & Included \\
\hline adj. $R^{2}$ & & 0.165 & 0.287 & 0.194 & 0.165 & 0.286 & 0.194 \\
\hline $\mathrm{F}$ & & $117.300^{* * *}$ & $119.259^{* * *}$ & $71.941 * * *$ & $97.774 * * *$ & $99.316^{* * *}$ & $60.058^{* * *}$ \\
\hline $\mathrm{N}$ & & 2945 & 1472 & 1473 & 2945 & 1472 & 1473 \\
\hline
\end{tabular}

Notes: ${ }^{* *} p<0.05,{ }^{* * *} p<0.01 . t$-values are in parentheses. 
The advertising intensity is statistically significant in the estimate of all firms $\left(\alpha_{1}=0.078, t=5.117\right)$ and small firms $\left(\alpha_{1}=0.153, t=6.887\right)$ but not in the large firm sample. This evidence suggests that advertising does encourage innovative activities only for small firms, so H1 is partially supported. Advertising and R\&D activities should be viewed as complementary activities rather than as substitute ones, inconsistent with Lunn's [68] finding that they may be substitutes in terms of competing for dollars allocated by the firm's management. In South Korea, about 75 percent of the firms in our studies achieved their expectations of making profit. When the actual firm performance is beyond expectation, firms are more likely to increase investments in $R \& D$ and advertising [69,70]. The coefficient of AD in small firms is bigger than that in large firms, so H5a is rejected.

In terms of the control variables, the negative coefficients on Lev indicate that firms with fewer debts tend to engage in more research activities. The growth variable (Sales) has an insignificant coefficient at a $5 \%$ confidence level.

For the entire data set of Equation (2), the negative effect on ROA of $R D\left(\beta_{1}=-0.247, t=-2.946\right)$ is highly significant. This is because $R \& D$ activities are generally long-term activities lasting for over one year and need a long period of time to bring profits to the company, from new product development to the commercialization of a product. For small firms, the coefficient of $\operatorname{RD}\left(\beta_{1}=-0.377, t=-2.809\right)$ is similar to that of the full sample. The result indicates that R\&D investment has a negative effect for small firms, rejecting $\mathrm{H} 2$. Though the coefficient of RD is positive and non-significant in the large firm sample, this also provides support for $\mathrm{H} 5 \mathrm{~b}$.

The coefficient of AD in large firms is positive and significant $\left(\beta_{2}=0.285, t=4.832\right)$. However, for small firms the coefficient of $\mathrm{AD}\left(\beta_{2}=-0.265, \mathrm{t}=-2.065\right)$ is very different, so H3 is partially supported. Indeed, large firms use advertising to differentiate their products and make their demand more inelastic. Large firms invest more in advertising than small firms, because advertising can help them to increase sales. Small firms spend high levels of advertising monies in order to bring new product to the market's notice in the face of existing brand loyalties [71]. In addition, there is evidence that supports $\mathrm{H} 5 \mathrm{c}$, because advertising intensity has a positive and significant effect on the performance of big firms and a negative and significant effect on the performance of small ones.

In Equation (3), the coefficients of the interaction effect are not significant in two groups. Therefore, $\mathrm{H} 4$ and $\mathrm{H} 5 \mathrm{~d}$ are not fully supported.

Only Asset and Lev retain a statistical significance and the same signs as the full sample. As was expected, Asset has a positive impact on ROA, while Lev has a negative influence. When the debt ratio increases by $1 \%$, the financial performance decreases accordingly by $16 \%$.

The results here are, in general, complementary to those reported by Chauvin and Hirschey [1], Han and Manry [4], Peterson and Jeong [5], Sridhar et al. [7], Nakao [25], Ho et al. [58], Tokic [59], and Lunn [68].

\subsection{Robustness Check}

First, we use Equation (4) to re-examine H1 and H5a. The regression results of Equation (4) are similar to the results of Table 4, which suggests that R\&D and advertising are complementary in South Korea. In addition, we also exclude observations for firms without R\&D investment, firms without advertising investment, and firms without $R \& D$ and advertising investment. Through an empirical analysis, we find that the results are still similar to the results of Tables 4 and 5. Finally, we use the return on investment (ROI), measured by the operating income divided by the average total assets, to re-measure the financial performance and re-estimate all equations. The results are similar to our previous findings (See Table 6).

$$
\mathrm{AD}_{\mathrm{i}, \mathrm{t}}=\delta_{0}+\delta_{1} \mathrm{RD}_{\mathrm{i}, \mathrm{t}}+\delta_{2} \mathrm{Asset}_{\mathrm{i}, \mathrm{t}}+\delta_{3} \operatorname{Lev}_{\mathrm{i}, \mathrm{t}}+\delta_{4} \text { Sales }_{\mathrm{i}, \mathrm{t}}+\text { Year }_{\mathrm{t}}+\varepsilon_{\mathrm{i}, \mathrm{t}}
$$


Table 6. Regression results of the robustness check.

\begin{tabular}{|c|c|c|c|c|c|c|c|}
\hline \multirow{2}{*}{ Variable } & \multirow{2}{*}{$\begin{array}{l}\text { Predicted } \\
\text { Sign }\end{array}$} & \multicolumn{3}{|c|}{ Equation (2) } & \multicolumn{3}{|c|}{ Equation (3) } \\
\hline & & All & Large Firms & Small Firms & All & Large Firms & Small Firms \\
\hline Constant & $?$ & $\begin{array}{l}-0.204^{* * *} \\
(-10.566)\end{array}$ & $\begin{array}{c}0.121^{* * *} \\
(4.989)\end{array}$ & $\begin{array}{l}-0.676^{* * *} \\
(-10.652)\end{array}$ & $\begin{array}{l}-0.204^{* * *} \\
(-10.584)\end{array}$ & $\begin{array}{c}0.119^{* * *} \\
(4.925)\end{array}$ & $\begin{array}{l}-0.676^{* * *} \\
(-10.642)\end{array}$ \\
\hline RD & + & $\begin{array}{c}-0.174^{* * *} \\
(-2.666)\end{array}$ & $\begin{array}{l}0.118^{*} \\
(1.782)\end{array}$ & $\begin{array}{c}-0.315^{* * *} \\
(-2.845)\end{array}$ & $\begin{array}{c}-0.207^{* *} \\
(-2.502)\end{array}$ & $\begin{array}{c}0.071 \\
(0.780)\end{array}$ & $\begin{array}{c}-0.362 * * * \\
(-2.688)\end{array}$ \\
\hline $\mathrm{AD}$ & + & $\begin{array}{c}0.180 * * * \\
(3.329)\end{array}$ & $\begin{array}{c}0.301 * * * \\
(5.666)\end{array}$ & $\begin{array}{l}-0.032 \\
(-0.335)\end{array}$ & $\begin{array}{c}0.165^{* * *} \\
(2.820)\end{array}$ & $\begin{array}{c}0.288^{* * *} \\
(5.134)\end{array}$ & $\begin{array}{l}-0.062 * \\
(-0.577)\end{array}$ \\
\hline $\mathrm{RD} \times \mathrm{AD}$ & + & & & & $\begin{array}{c}1.973 \\
(0.651)\end{array}$ & $\begin{array}{c}3.037 \\
(0.755)\end{array}$ & $\begin{array}{c}2.655 \\
(0.615)\end{array}$ \\
\hline Asset & + & $\begin{array}{l}0.024 * * * \\
(14.270)\end{array}$ & $\begin{array}{c}-0.002 \\
(-1.033)\end{array}$ & $\begin{array}{l}0.066^{* * *} \\
(11.664)\end{array}$ & $\begin{array}{l}0.024 * * * \\
(14.283)\end{array}$ & $\begin{array}{c}-0.002 \\
(-0.974)\end{array}$ & $\begin{array}{l}0.066^{* * *} \\
(11.660)\end{array}$ \\
\hline Lev & - & $\begin{array}{l}-0.097 * * * \\
(-16.242)\end{array}$ & $\begin{array}{l}-0.099 * * * \\
(-15.098)\end{array}$ & $\begin{array}{l}-0.098^{* * *} \\
(-10.413)\end{array}$ & $\begin{array}{l}-0.097^{* * * *} \\
(-16.250)\end{array}$ & $\begin{array}{l}-0.099 * * * \\
(-15.081)\end{array}$ & $\begin{array}{l}-0.098^{* * *} \\
(-10.422)\end{array}$ \\
\hline Sales & + & $\begin{array}{l}-0.00001 \\
(-0.070)\end{array}$ & $\begin{array}{c}-0.00001 \\
(-0.087)\end{array}$ & $\begin{array}{c}0.008^{* * *} \\
(3.217)\end{array}$ & $\begin{array}{c}-0.00001 \\
(-0.076)\end{array}$ & $\begin{array}{l}-0.00001 \\
(-0.095)\end{array}$ & $\begin{array}{c}0.008^{* * *} \\
(3.194)\end{array}$ \\
\hline $\begin{array}{c}\text { Year } \\
\text { adj. } R^{2}\end{array}$ & & $\begin{array}{c}\text { Included } \\
0.120\end{array}$ & $\begin{array}{c}\text { Included } \\
0.189\end{array}$ & $\begin{array}{c}\text { Included } \\
0.139\end{array}$ & $\begin{array}{c}\text { Included } \\
0.120\end{array}$ & $\begin{array}{c}\text { Included } \\
0.189\end{array}$ & $\begin{array}{c}\text { Included } \\
0.138\end{array}$ \\
\hline $\mathrm{F}$ & & $81.317^{* * *}$ & $69.524^{* * *}$ & $48.364^{* * *}$ & $67.822 * * *$ & $58.015^{* * *}$ & $40.349^{* * *}$ \\
\hline $\mathrm{N}$ & & 2945 & 1472 & 1473 & 2945 & 1472 & 1473 \\
\hline
\end{tabular}

Following previous research [72,73], we also introduce the previous year's ROA into Equations (2) and (3). The regression results are shown in Table 7, similar to the previous results.

Table 7. Regression results of Equations (2) and (3).

\begin{tabular}{|c|c|c|c|c|c|c|c|}
\hline \multirow{2}{*}{ Variable } & \multirow{2}{*}{$\begin{array}{l}\text { Predicted } \\
\text { Sign }\end{array}$} & \multicolumn{3}{|c|}{ Equation (2) } & \multicolumn{3}{|c|}{ Equation (3) } \\
\hline & & All & Large Firms & Small Firms & All & Large Firms & Small Firms \\
\hline Constant & $?$ & $\begin{array}{c}-0.125 * * * \\
(-5.245)\end{array}$ & $\begin{array}{l}0.046^{*} \\
(1.760)\end{array}$ & $\begin{array}{c}-0.439 * * * \\
(-5.083)\end{array}$ & $\begin{array}{c}-0.125^{* * *} \\
(-5.244)\end{array}$ & $\begin{array}{l}0.047^{*} \\
(1.802)\end{array}$ & $\begin{array}{c}-0.439 * * * \\
(-5.080)\end{array}$ \\
\hline RD & + & $\begin{array}{l}-0.146^{*} \\
(-1.889)\end{array}$ & $\begin{array}{c}0.046 \\
(0.656)\end{array}$ & $\begin{array}{l}-0.254^{*} \\
(-1.796)\end{array}$ & $\begin{array}{c}-0.154 \\
(-1.567)\end{array}$ & $\begin{array}{c}0.088 \\
(0.909)\end{array}$ & $\begin{array}{l}-0.285^{*} \\
(-1.650)\end{array}$ \\
\hline $\mathrm{AD}$ & + & $\begin{array}{l}0.065^{*} \\
(0.313)\end{array}$ & $\begin{array}{l}0.116^{* *} \\
(2.010)\end{array}$ & $\begin{array}{c}-0.018 \\
(-0.144)\end{array}$ & $\begin{array}{l}0.062 * \\
(0.890)\end{array}$ & $\begin{array}{l}0.128 * * \\
(2.106)\end{array}$ & $\begin{array}{c}-0.036 \\
(-0.264)\end{array}$ \\
\hline $\mathrm{RD} \times \mathrm{AD}$ & + & & & & $\begin{array}{c}0.467 \\
(0.132)\end{array}$ & $\begin{array}{c}-2.661 \\
(-0.630)\end{array}$ & $\begin{array}{c}1.673 \\
(0.311)\end{array}$ \\
\hline Asset & + & $\begin{array}{c}0.015^{* * *} \\
(6.818)\end{array}$ & $\begin{array}{c}0.001 \\
(0.566)\end{array}$ & $\begin{array}{c}0.043^{* * *} \\
(5.517)\end{array}$ & $\begin{array}{c}0.015^{* * *} \\
(6.811)\end{array}$ & $\begin{array}{c}0.001 \\
(0.511)\end{array}$ & $\begin{array}{c}0.043^{* * *} \\
(5.517)\end{array}$ \\
\hline Lev & - & $\begin{array}{l}-0.078^{* * *} \\
(-10.309)\end{array}$ & $\begin{array}{l}-0.090^{* * *} \\
(-11.236)\end{array}$ & $\begin{array}{c}-0.088^{* * *} \\
(-7.004)\end{array}$ & $\begin{array}{l}-0.078^{* * *} \\
(-10.306)\end{array}$ & $\begin{array}{l}-0.090^{* * *} \\
(-11.236)\end{array}$ & $\begin{array}{c}-0.088^{* * *} \\
(-7.008)\end{array}$ \\
\hline Sales & + & $\begin{array}{c}0.019^{* * *} \\
(7.990)\end{array}$ & $\begin{array}{c}0.058^{* * *} \\
(7.948)\end{array}$ & $\begin{array}{c}0.017^{* * *} \\
(5.909)\end{array}$ & $\begin{array}{c}0.019 * * * \\
(7.988)\end{array}$ & $\begin{array}{c}0.058^{* * * *} \\
(7.965)\end{array}$ & $\begin{array}{c}0.017^{* * *} \\
(5.906)\end{array}$ \\
\hline $\begin{array}{c}\text { Previous } \\
\text { year's } \\
\text { ROA }\end{array}$ & + & $\begin{array}{l}0.525^{* * *} \\
(31.352)\end{array}$ & $\begin{array}{l}0.379 * * * \\
(15.626)\end{array}$ & $\begin{array}{l}0.519 * * * \\
(21.210)\end{array}$ & $\begin{array}{l}0.525^{* * *} \\
(31.338)\end{array}$ & $\begin{array}{l}0.379 * * * \\
(15.612)\end{array}$ & $\begin{array}{l}0.519 * * * \\
(21.178)\end{array}$ \\
\hline Year & & Included & Included & Included & Included & Included & Included \\
\hline adj. $R^{2}$ & & 0.415 & 0.445 & 0.413 & 0.415 & 0.445 & 0.413 \\
\hline $\mathrm{F}$ & & $279.716^{* * *}$ & $158.745^{* * *}$ & $138.914^{* * *}$ & 239.659 & $136.054^{* * *}$ & 118.991 \\
\hline $\mathrm{N}$ & & 2356 & 1180 & 1176 & 2356 & 1180 & 1176 \\
\hline
\end{tabular}

Notes: ${ }^{*} p<0.10,{ }^{* *} p<0.05,{ }^{* * *} p<0.01 . t$-values are in parentheses.

In order to ensure the robustness of our results, we use the fixed effect model to re-estimate Equations (2) and (3). From the Hausman test, the fixed effect model is more reliable than the random effect model. The results are presented in Table 8 , similar to the previous results. 
Table 8. Regression results of Equations (2) and (3).

\begin{tabular}{|c|c|c|c|c|c|c|c|}
\hline \multirow{2}{*}{ Variable } & \multirow{2}{*}{$\begin{array}{l}\text { Predicted } \\
\text { Sign }\end{array}$} & \multicolumn{3}{|c|}{ Equation (2) } & \multicolumn{3}{|c|}{ Equation (3) } \\
\hline & & All & Large Firms & Small Firms & All & Large Firms & Small Firms \\
\hline Constant & $?$ & $\begin{array}{c}-1.012 * * * \\
(-6.23)\end{array}$ & $\begin{array}{l}-0.069 \\
(-0.39)\end{array}$ & $\begin{array}{c}-2.132 * * * \\
(-6.98)\end{array}$ & $\begin{array}{c}-1.010^{* * *} \\
(-6.21)\end{array}$ & $\begin{array}{l}-0.070 \\
(-0.39)\end{array}$ & $\begin{array}{c}-2.140^{* * *} \\
(-6.99)\end{array}$ \\
\hline $\mathrm{RD}$ & + & $\begin{array}{c}-0.915^{* * *} \\
(-4.74)\end{array}$ & $\begin{array}{l}-0.937 \\
(-4.03)\end{array}$ & $\begin{array}{c}-0.744^{* *} \\
(-2.54)\end{array}$ & $\begin{array}{c}-0.873^{* * *} \\
(-4.03)\end{array}$ & $\begin{array}{l}-1.054 \\
(-4.00)\end{array}$ & $\begin{array}{c}-0.816^{* *} \\
(-2.48)\end{array}$ \\
\hline $\mathrm{AD}$ & + & $\begin{array}{l}0.040 \\
(0.27)\end{array}$ & $\begin{array}{c}0.574 \text { ** } \\
(2.35)\end{array}$ & $\begin{array}{c}-0.741 \text { ** } \\
(-2.89)\end{array}$ & $\begin{array}{l}0.059 \\
(0.38)\end{array}$ & $\begin{array}{c}0.515 * * \\
(2.04)\end{array}$ & $\begin{array}{c}-0.798^{* *} \\
(-2.82)\end{array}$ \\
\hline $\mathrm{RD} \times \mathrm{AD}$ & + & & & & $\begin{array}{l}-2.247 \\
(-0.42)\end{array}$ & $\begin{array}{l}8.541 \\
(0.94)\end{array}$ & $\begin{array}{l}3.569 \\
(0.48)\end{array}$ \\
\hline Asset & + & $\begin{array}{c}0.102^{* * *} \\
(7.28)\end{array}$ & $\begin{array}{l}0.022 \\
(1.46)\end{array}$ & $\begin{array}{c}0.205^{* * *} \\
(7.44)\end{array}$ & $\begin{array}{c}0.102^{* * *} \\
(7.26)\end{array}$ & $\begin{array}{l}0.022 \\
(1.47)\end{array}$ & $\begin{array}{c}0.206^{* * *} \\
(7.45)\end{array}$ \\
\hline Lev & - & $\begin{array}{c}-0.330^{* * *} \\
(-18.37)\end{array}$ & $\begin{array}{c}-0.309^{* * *} \\
(-13.11)\end{array}$ & $\begin{array}{c}-0.340^{* * *} \\
(-12.98)\end{array}$ & $\begin{array}{c}-0.330^{* * *} \\
(-18.33)\end{array}$ & $\begin{array}{c}-0.310^{* * *} \\
(-13.14)\end{array}$ & $\begin{array}{c}-0.340^{* * *} \\
(-12.99)\end{array}$ \\
\hline Sales & + & $\begin{array}{c}-0.0003 \\
(-1.34)\end{array}$ & $\begin{array}{c}-0.0001 \\
(-0.90)\end{array}$ & $\begin{array}{c}0.119^{* * *} \\
(4.47)\end{array}$ & $\begin{array}{c}-0.0003 \\
(-1.34)\end{array}$ & $\begin{array}{l}-0.0001 \\
(-0.90)\end{array}$ & $\begin{array}{c}0.119^{* * *} \\
(4.47)\end{array}$ \\
\hline $\begin{array}{c}\text { Year } \\
\text { adj. } R^{2}\end{array}$ & & $\begin{array}{c}\text { Included } \\
0.154\end{array}$ & $\begin{array}{c}\text { Included } \\
0.257\end{array}$ & $\begin{array}{c}\text { Included } \\
0.197\end{array}$ & $\begin{array}{c}\text { Included } \\
0.154\end{array}$ & $\begin{array}{c}\text { Included } \\
0.257\end{array}$ & $\begin{array}{c}\text { Included } \\
0.197\end{array}$ \\
\hline $\mathrm{F}$ & & $44.70 * * *$ & $24.68^{* * *}$ & $26.93^{* * *}$ & $40.24^{* * *}$ & $22.30^{* * *}$ & $24.24^{* * *}$ \\
\hline $\mathrm{N}$ & & 2945 & 1472 & 1473 & 2945 & 1472 & 1473 \\
\hline
\end{tabular}

\subsection{Additional Analysis on the Duration of RED and Advertising}

It generally takes a pretty long time to get from the initial stage of the R\&D activity to a new product entry into the market. Positive influence cannot be imposed on the firm profitability at once [62]. The advertising investment has a long-term effect for large firms [74]. It is reasonable to expect a lagged relationship between $R \& D$ and advertising expenditures, and firms' financial performance. Such lags are supported by Boulding and Staelin [75], who empirically justified the use of 1-year lags when investigating the impact of R\&D on the financial performance; and by Peterson and Jeong [5] and Ho et al. [58], who found differential lag effects of R\&D and advertising expenditures.

Based on the analysis of the full sample, Table 9 demonstrates the effects of simultaneity and the lagged effects of $R \& D$ and the advertising intensity on the financial performance. The relationship between RD and ROA first becomes negative and significant, and, after a 2-year period, it becomes positive but insignificant. The relationship between $\mathrm{AD}$ and ROA shows a gradually weakening trend. Although the relationship between $\mathrm{AD}$ and ROA is not statistically significant, after two years this relationship becomes negative. One reasonable explanation for this is that the advertising input is based on a short-term goal, whereas the R\&D input is focused on long-term returns for Korean firms. Many businesses push short-term advertising strategies as they seek the instant gratification their consumers crave.

Table 9. Regression results of the lagged effect of R\&D and advertising.

\begin{tabular}{|c|c|c|c|}
\hline Variable & $t$ & $t-1$ & $t-2$ \\
\hline Constant & $\begin{array}{l}-0.306^{* * *} \\
(-12.340)\end{array}$ & $\begin{array}{l}-0.301 * * * \\
(-10.916)\end{array}$ & $\begin{array}{c}-0.307^{* * *} \\
(-9.405)\end{array}$ \\
\hline $\mathrm{RD}$ & $\begin{array}{c}-0.247^{* * *} \\
(-2.946)\end{array}$ & $\begin{array}{l}-0.125^{*} \\
(-1.288)\end{array}$ & $\begin{array}{c}0.002 \\
(0.016)\end{array}$ \\
\hline $\mathrm{AD}$ & $\begin{array}{c}0.082 \\
(1.182)\end{array}$ & $\begin{array}{c}0.027 \\
(0.348)\end{array}$ & $\begin{array}{c}-0.045 \\
(-0.495)\end{array}$ \\
\hline Asset & $\begin{array}{l}0.034^{* * *} \\
(15.709)\end{array}$ & $\begin{array}{l}0.034^{* * *} \\
(13.855)\end{array}$ & $\begin{array}{l}0.034^{* * *} \\
(11.794)\end{array}$ \\
\hline Lev & $\begin{array}{l}-0.165^{* * *} \\
(-21.443)\end{array}$ & $\begin{array}{l}-0.163^{* * *} \\
(-19.214)\end{array}$ & $\begin{array}{l}-0.157^{* * * *} \\
(-15.758)\end{array}$ \\
\hline Sales & $\begin{array}{l}-0.0002 \\
(-0.731)\end{array}$ & $\begin{array}{c}0.013^{* * *} \\
(4.827)\end{array}$ & $\begin{array}{c}0.025^{* * *} \\
(4.337)\end{array}$ \\
\hline Year & Included & Included & Included \\
\hline adj. $R^{2}$ & 0.165 & 0.168 & 0.158 \\
\hline $\mathrm{F}$ & $117.300^{* * *}$ & $96.417^{* * *}$ & $67.359^{* * *}$ \\
\hline $\mathrm{N}$ & 2945 & 2356 & 1767 \\
\hline
\end{tabular}




\section{Conclusions}

In this study, we consider how the financial performance is improved when R\&D and advertising are considered as important sources of intangible capital. This study also examines whether firm size affects the impact of $R \& D$ and advertising expenditures on the financial performance. The study findings provide theoretical contributions and implications on R\&D-advertising research. First, this study provides evidence that $R \& D$ and advertising are complementary for Korean listed firms. This is consistent with the findings of Farber [24], Nakao [25], and Ren [26]. This study extends the previous research on the relationship between $R \& D$ and advertising by using data from South Korea, an emerging market with a high level of investment in R\&D and advertising activities. Second, this research increases our body of knowledge by identifying the impact of the firm size on the relationship between $R \& D$ and advertising expenditures, and the financial performance. That is, advertising is positively and significantly associated with the financial performance of large firms, and R\&D expenditure has no significant influence; $R \& D$ and advertising expenditures have a negative impact on the financial performance of small firms. It is also noted that the current research examines the lagged effects of R\&D and advertising on the financial performance. We find that the advertising input is based on a short-term goal, whereas the R\&D input is focused on long-term returns for Korean firms.

The findings of this study may have several practical implications. First, Korean firms should adopt an optimal mix of R\&D and advertising investments and specialize only in those resources in which they have a core competence or comparative advantage. Meanwhile, Korean firms should make substantial and continuous investments in R\&D activities, since R\&D activities are generally long-term activities lasting for over one year that need a long period of time to bring profits. In addition, Korean firms should also make reasonable investments in advertising to build up a corporate reputation in the global market.

Second, managers in large firms should make full use of resources that have a comparative advantage or seek a synergy between R\&D and advertising by improving the efficiency of the budget allocation and marginal control. Given the limited resources, managers in SMEs should focus as many of the firm's resources as possible on R\&D and marketing strategies.

Finally, the Korean government should provide a series of tax incentives and R\&D subsidies for small firms to stimulate them to increase R\&D inputs. Meanwhile, the Korean government should make related regulations to forbid Korean firms from depending on an excessive investment in advertising.

This research work has some limitations. First, external factors that might affect the financial performance should be taken into consideration, including competitors' marketing strategies, industry concentration and new product, etc. Second, the research could be extended to compare firms in different industries to examine the industry effect. This may give some additional insight into other economic impacts besides the firm size that contribute to a firm's performance. Finally, the findings should be interpreted with care in the case of other countries or regions. Therefore, further research on the subject appears warranted.

Author Contributions: Conceptualization, J.X.; methodology, J.X. and F.L.; software, J.X. and F.L.; validation, J.X., F.L. and Y.-h.C.; formal analysis, J.X.; data curation, J.X.; writing—original draft preparation, J.X. and F.L.; writing-review and editing, F.L. and Y.-h.C.

Funding: This research received no external funding.

Acknowledgments: We would like to thank the editor and the anonymous reviewers for their useful comments on earlier drafts.

Conflicts of Interest: The authors declare no conflict of interest.

\section{References}

1. Chauvin, K.W.; Hirschey, M. Advertising, R\&D expenditures and the market value of the firm. Financ. Manag. 1993, 22, 128-140.

2. Wernerfelt, B. A resource-based view of the firm. Strateg. Manag. J. 1984, 5, 171-180. [CrossRef] 
3. Henri, J.F. Management control systems and strategy: A resource-based perspective. Account. Org. Soc. 2006, 31, 529-558. [CrossRef]

4. Han, B.H.; Manry, D. The value-relevance of R\&D and advertising expenditures: Evidence from Korea. Int. J. Account. 2004, 39, 155-173.

5. Peterson, R.A.; Jeong, J. Exploring the impact of advertising and R\&D expenditures on corporate brand value and firm-level financial performance. J. Acad. Mark. Sci. 2010, 38, 677-690.

6. Bhagwat, Y.; DeBruine, M. R\&D and advertising efficiencies in the pharmaceutical industry. Int. J. Appl. Econ. 2011, 8, 55-65.

7. Sridhar, S.; Narayanan, S.; Srinivasan, R. Dynamic relationships among R\&D, advertising, inventory and firm performance. J. Acad. Mark. Sci. 2014, 42, 277-290.

8. Peng, C.; Wei, A.; Chen, M.; Huang, W. Synergy between R\&D and advertising on shareholder value: Does firm size matter? Can. J. Adm. Sci. 2018, 35, 47-64.

9. Sung, J.K.; Park, J.; Yoo, S. Exploring the impact of strategic emphasis on advertising versus R\&D during stock market downturns and upturns. J. Bus. Res. 2019, 94, 56-64.

10. McAlister, L.; Srinivasan, R.; Kim, M. Advertising, research and development, and systematic risk of the firm. J. Mark. 2007, 71, 35-48. [CrossRef]

11. Chen, M.L.; Peng, C.L.; Wei, A.P. Advertising, research and development, and capital market risk: Higher risk firms versus lower risk firms. J. Bus. Econ. Manag. 2012, 13, 724-744. [CrossRef]

12. Bublitz, B.; Ettredge, M. The information in discretionary outlays: Advertising, research, and development. Account. Res. 1989, 64, 108-124.

13. Lantz, J.S.; Sahut, J.M. R\&D investment and the financial performance of technological firms. Int. J. Bus. 2005, 10, 251-270.

14. Steenkamp, J.B.E.M.; Fang, E. The impact of economic contractions on the effectiveness of R\&D and advertising: Evidence from U.S. companies spanning three decades. Market. Sci. 2011, 30, 628-645.

15. Min, B.S.; Smyth, R. How does leverage affect R\&D intensity and how does R\&D intensity impact on firm value in South Korea? Appl. Econ. 2016, 48, 5667-5675.

16. Askenazy, P.; Breda, T.; Irac, D. Advertising and R\&D: Theory and evidence from France. Econ. Innov. New Tech. 2016, 25, 33-56.

17. Kim, J.Y. The effect of adopting K-IFRS on financial reports-Case study with KT\&G. Int. J. Multimed. Ubiquitous Eng. 2013, 8, 205-212.

18. Pindado, J.; de Queiroz, V.; de la Torre, C. How do firm characteristics influence the relationship between R\&D and firm value? Financ. Manage. 2010, 39, 757-782.

19. Scherer, F.M.; Ross, D. Industrial Market Structure and Economic Performance; Houghton Mifflin: Boston, MA, USA, 1990.

20. Li, C.W. An Empirical Study on the Predictability of R\&D Costs and Advertising Expenditures to the Accounting Income. Ph.D. Thesis, Dankook University, Yongin-si, Korea, 1994.

21. Heo, S.H. R\&D expenditures, Advertising Expenditures and Firm Valuation of KOSDAQ Securities. Master's Thesis, Kyung Hee University, Seoul, Korea, 2002.

22. Zhang, R.; Fu, X.F. Analysis for optimal R\&D and advertising investment strategies. Sci. Technol. Prog. Policy 2010, 27, 86-90. (In Chinese)

23. Connolly, R.A.; Hirschey, M. R\&D, market structure, and profits: A value-based approach. Rev. Econ. Stat. 1984, 66, 682-686.

24. Farber, S.C. Buyer market structure and R\&D effort: A simultaneous equations model. Rev. Econ. Stat. 1981, 63, 336-345.

25. Nakao, T. Market share, advertising, R\&D, and profitability: An empirical analysis of leading industrial firms in Japan. Rev. Ind. Organ. 1993, 8, 315-328.

26. Ren, H.Y. Research on the Value Relevance of Advertising Expenditure and R\&D Expenditure. Sci. Res. Manag. 2014, 35, 153-160. (In Chinese)

27. Graevenitz, G.V.; Sandner, P. Are Advertising and R\&D Complements? Available online: https://ssrn.com/ abstract $=1443415$ (accessed on 17 June 2019).

28. Chen, Y.H.; Nie, P.Y.; Peng, B.Y. Advertising and R\&D innovation under debt constraint. Chin. J. Manag. Sci. 2015, 23, 142-149. (In Chinese)

29. Paton, D. Advertising, quality and sales. Appl. Econ. 2002, 34, 431-438. [CrossRef] 
30. Nakao, T. Profitability, market share, product quality, and advertising in oligopoly. J. Econ. Dyn. Control 1983, 6, 153-171. [CrossRef]

31. Hirschey, M.; Weygandt, J.J. Amortization policy for advertising and research and development expenditures. J. Account. Res. 1985, 23, 326-335. [CrossRef]

32. Hall, B.H. The stock market's valuation of R\&D investment during the 1980's. Am. Econ. Rev. 1993, 83, 259-264.

33. Andras, T.L.; Srinivasan, S.S. Advertising intensity and R\&D intensity: Differences across industries and their impact on firm's performance. Int. J. Bus. Econ. 2003, 2, 167-176.

34. Li, Q.Y. R\&D and advertising expenditures: Expensing or capitalization-Empirical evidence from manufacturing listed corporations in China. Commun. Finan. Account. Acad. Version. 2006, 10, 3-7. (In Chinese)

35. Xing, S.; Yang, Y. An empirical study on R\&D, advertising investment and main operating profit of traditional Chinese medicine. Chin. J. Pharm. 2009, 40, 474-476. (In Chinese)

36. Ma, Y.Y.; Zhang, X.L.; Lu, Y.W. R\&D expenditure, advertising expenditure, and enterprise economic performance: Based on empirical analysis of Chinese manufacturing sub-sectors. J. Dalian Univ. Technol. Soc. Sci. 2015, 36, 30-34. (In Chinese)

37. Chan, S.H.; Martin, J.D.; Kensinger, J.W. Corporate research and development expenditures and share value. J. Financ. Econ. 1990, 26, 255-276. [CrossRef]

38. Doukas, J.; Switzer, L. The stock market's valuation of R\&D spending and market concentration. J. Econ. Bus. 1992, 44, 95-114.

39. Cho, S.P.; Lim, K.; Kwon, G.J.; Sung, Y.H. R\&D investment and performance in Korea: Korean R\&D scoreboard 2005. Asian, J. Technol. Innov. 2008, 16, 143-160.

40. Depken, C.A.; Snow, A. The strategic nature of advertising in segmented markets. Appl. Econ. 2008, 40, 2987-2994. [CrossRef]

41. Mai, Y.Y.; Li, Y. Impact of advertising and R\&D expenditures on brand equity of new ventures. Sci. Res. Manag. 2016, 37, 137-144. (In Chinese)

42. Fogg-Meade, E. The place of advertising in modern business. J. Political Econ. 1901, 9, 218-242. [CrossRef]

43. Jin, Z.J.; Shang, Y.; Xu, J. The impact of government subsidies on private R\&D and firm performance: Does ownership matter in China's manufacturing industry. Sustainability 2018, 10, 2205.

44. Gómez, J.; Vargas, P. Intangible resources and technology adoption in manufacturing firms. Res. Policy 2012, 41, 1607-1619. [CrossRef]

45. Shim, D.; Kim, J.G.; Altmann, J. Strategic Managment of R\&D and marketing integration for multi-dimensional success of new product developments: An empirical investigation in the Korean ICT industry. Asian J. Technol. Innov. 2016, 24, 293-316.

46. Zhu, G.L.; Zhang, Y.; Chen, K.H.; Yu, J. The impact of R\&D intensity on firm performance in an emerging market: Evidence from China's electronics manufacturing firms. Asian J. Technol. Innov. 2017, 25, 41-60.

47. Xu, J.; Sim, J.W. Characteristics of corporate R\&D investment in emerging markets: Evidence from manufacturing industry in China and South Korea. Sustainability 2018, 10, 3002.

48. Mavrommati, A.; Papadopoulos, A. Measuring advertising intensity and intangible capital in the Greek food industry. Appl. Econ. 2005, 37, 1777-1787. [CrossRef]

49. Doraszelski, U.; Markovich, S. Advertising dynamics and competitive advantage. RAND J. Econ. 2007, 38, 557-592. [CrossRef]

50. Das, B.J.; Chappell, W.F.; Shughartii, W.F. Advertising, competition and market share instability. Appl. Econ. 1993, 25, 1409-1412. [CrossRef]

51. Jeong, J. Advertising vs. R\&D: Relative effectiveness on brand equity. S. Afr. J. Bus. Manag. 2015, 46, 31-42.

52. Kang, T.; Baek, C.; Lee, J.D. R\&D activities for becoming a high-growth firm through large jumps: Evidence from Korean manufacturing. Asian J. Technol. Innov. 2018, 26, 222-245.

53. Kang, H.; Mah, J.S. R\&D policy for small and medium-sized enterprises in Korea. Sci. Technol. Soc. 2015, 20,1-20.

54. Sun, W.F.; Huang, Z.H. Advertising expenditure, R\&D expenditure, and firm performance. Sci. Res. Manag. 2013, 34, 44-51. (In Chinese)

55. Eng, L.L.; Keh, H.T. The effects of advertising and brand value on future operating and market performance. J. Advert. 2007, 36, 91-100. [CrossRef] 
56. Luo, Y.J.; Chen, X.; He, L.T. The relations among social donation, advertising expenditure and performance of Chinese agricultural listed companies. J. Anhui Agric. Univ. Soc. 2016, 25, 44-49. (In Chinese)

57. Zhang, H.; Li, L.; Zhou, D.; Zhou, P. Political connections, government subsidies and firm financial performance: Evidence from renewable energy manufacturing in China. Renew. Energy 2014, 63, 330-336. [CrossRef]

58. Ho, Y.K.; Keh, H.T.; Ong, J.M. The effects of R\&D and advertising on firm value: An examination of manufacturing and nonmanufacturing firms. IEEE Trans. Eng. Mana. 2005, 52, 3-14.

59. Tokic, D. R\&D, advertising and the market value of Internet firms: Part II. J. Internet Commer. 2005, 4, $23-40$.

60. Jung, K.O.; Chang, W.K.; Kim, Y.Y. The relationships between R\&D, advertising expenses and the market value of the firms in Korean manufacturing industry. Korean J. Bus. Adm. 2005, 18, 1851-1867. (In Korean)

61. Qiao, J. R\&D and ad impact on the efficiency of enterprise technology research: Based on an empirical analysis of the food Industry Listed Companies in China. Nanjing J. Soc. Sci. 2015, 4, 23-29. (In Chinese)

62. He, F.; Chen, R. R\&D, advertising and firm technical efficiency: An empirical analysis on Chinese and Japanese household appliance industry. Int. J. Serv. Technol. Manag. 2011, 16, 107-122.

63. Kim, P.R. R\&D and firm sizes in the information and telecommunication industry of Korea. Small Bus. Econ. 2000, 15, 183-192.

64. Dong, X.Q.; Zhao, J.; Yuan, P.W. A study on the relationship between enterprise scale and technological innovation capacity. J. Beijing Jiaotong Univ. 2013, 12, 40-46. (In Chinese)

65. Jo, I.S.; Choi, N.S. An empirical study about value-relevance of R\&D costs and advertising expenses-A comparative analysis between KOSDAQ venture companies and KOSDAQ general companies. Korea Int. Account. Rev. 2005, 13, 111-137. (In Korean)

66. Li, Q.J.; Yin, S. Corporate social responsibility, advertising investment and enterprise value: Agricultural listed companies as samples. J. China Agric. Univ. 2015, 20, 281-287. (In Chinese)

67. Tsai, S.C. Valuation of R\&D and advertising expenditures. J. Contemp. Account. 2001, 2, 40-74.

68. Lunn, J. R\&D, concentration and advertising: A simultaneous equations model. Manag. Decis. Econ. 1989, 10, 101-105.

69. Tang, E.Z. The relationship between advertising tactic and R\&D strategy of enterprises in China. Res. Inst. Econ. 2017, 2, 87-110. (In Chinese)

70. Song, T.B.; Zhong, X.; Chen, W.H.; Wu, X.J. R\&D investment or advertising investment?-Choice of strategic behavior of firms in poor performance. $R$ D Manag. 2018, 30, 12-21. (In Chinese)

71. Reekie, W.D.; Bhoyrub, P. Profitability and intangible assets: Another look at advertising and entry barriers. Appl. Econ. 1981, 13, 99-107. [CrossRef]

72. Currim, I.S.; Lim, J.; Kim, J.W. You get what you pay for: The impact of top executives' compensation on advertising and R\&D spending decisions and stock market return. J. Mark. 2012, 76, 33-48.

73. Xiao, S.S.; Jeong, I.; Moon, J.J.; Chung, C.C.; Chung, J. Internationalization and performance of firms in China: Moderating effects of governance structure and the degree of centralized control. J. Int. Manag. 2013, 19, 118-137. [CrossRef]

74. Hirschey, M.; Spencer, R.S. Size effects in the market valuation of fundamental factors. Financ. Anal. J. 1992, 48, 91-95. [CrossRef]

75. Boulding, W.; Staelin, R. Identifying generalizable effects of strategic actions on firm performance: The case of demand-side returns to R\&D spending. Mark. Sci. 1995, 14, G222-G236.

(C) 2019 by the authors. Licensee MDPI, Basel, Switzerland. This article is an open access article distributed under the terms and conditions of the Creative Commons Attribution (CC BY) license (http://creativecommons.org/licenses/by/4.0/). 